\title{
Keluhan Sick Building Syndrome di Gedung PT. X
}

\author{
Fahruniza M. Mawarni, Mona Lestari", Yuanita Windusari, Desheila Andarini, Anita Camelia, \\ Rizka F. Nandini, Poppy Fujianti
}

Peminatan Keselamatan dan Kesehatan Kerja Program Studi Ilmu Kesehatan Masyarakat Fakultas Kesehatan Masyarakat Universitas Sriwijaya, Palembang

*Corresponding Author: mona_lestari@unsri.ac.id

Info Artikel:Diterima 19 September 2020 ; Disetujui 26 November 2020 ; Publikasi 1 April 2021

Cara sitasi (Vancouver): Mawarni FM, Lestari M, Windusari Y, Andarini D, Camelia A, Nandini RF, Fujianti P. Keluhan Sick Building Syndrome di Gedung PT. X. Jurnal Kesehatan Lingkungan Indonesia [Online]. 2021 Feb;20(1):39-46. https://doi.org/10.14710/jkli.20.1.39-46.

\begin{abstract}
ABSTRAK
Latar Belakang : Sick Building Syndrome (SBS) merupakan kumpulan gejala yang dialami oleh seseorang atau perasaan tidak sehat tanpa penyebab yang jelas saat melakukan pekerjaan di dalam gedung dan akan menghilang saat seseorang meninggalkan gedung tersebut. Sirkulasi udara yang tidak baik, ditambah dengan adanya faktor fisik, kimia, biologi, dan individu, serta faktor lingkungan lainnya yang terdapat di dalam suatu bangungan dapat menjadi penyebab terjadinya SBS. Oleh sebab itu, penelitian ini bertujuan untuk mengetahui faktor apa saja yang mempengaruhi keluhan SBS pada karyawan di gedung PT. X Palembang.

Metode: Penelitian ini menggunakan pendekatan kualitatif dengan desain studi cross sectional. Sampel penelitian sebanyak 107 karyawan yang terpilih sesuai dengan kriteria inklusi dan ekslusi yang telah ditetapkan. Analisis data yang digunakan adalah analisis univariat untuk melihat gambaran keluhan SBS, usia, jenis kelamn, masa kerja, suhu, pencahayaan dan kembaban, serta analisis bivariat dengan menggunakan uji chi-square dan uji alternatif fisher exact untuk melihat pengaruh faktor risiko terhadap keluhan SBS.

Hasil : Dari hasil penelitian diketahui bahwa prevalensi keluhan SBS sebesar 75,7\%, dengan usia terbanyak $\leq 40$ tahun $(80,4 \%)$, didominasi oleh laki-laki (60,7\%), dengan masa kerja paling banyak $\geq 5$ tahun $(62,6 \%)$, serta lingkungan kerja dengan suhu, pencahayaan, dan kelembaban yang tidak memenuhi syarat secara berurutan sebesar $18,7 \%, 49,5 \%$, dan $36,4 \%$.

Simpulan: Hasil analisis bivariat menunjukan bahwa kelembaban mempengaruhi terjadinya keluhan SBS pada karyawan PT. X Palembang ( $p$-value $=0,005)$. Untuk menyeimbangkan kualitas udara di dalam ruangan, salah satu upaya yang dapat dilakukan adalah dengan meletakkan tanaman sanseviera sebagai menyeimbang dan penyerap polutan di dalam ruangan.
\end{abstract}

Kata kunci: Sick Building Syndrome; Kelembaban; Pencahayaan; Polutan; Tanaman Sansevieria

\footnotetext{
ABSTRACT

Tittle : Sick Building Syndrome Complain in PT. X Building

Background : Sick Building Syndrome (SBS) is a syndrome where people experience unexplained malaise symptoms while working in a building that will disappear once they leave the building. Poor air circulation combined with the presence of physical, chemical, biological and individual factors, and other environmental factors within a building may cause SBS. This study aimed to determine factors that influence SBS complain among employees of PT. $X$ in Palembang.

Method: This study used a qualitative approach with cross sectional study design. The research sample was 107 employees selected according to inclusive and exclusive criteria. The data analysis methods in the study are univariate analysis to describe SBS complain, age, sex, years of service, temperature, lighting and humidity.
} 
Bivariate analysis using the chi-square test and fisher exact alternative test to determine risk factors influence to SBS complain.

Result : The prevalence of SBS complain in the study is 75,7\%, with $\$ 40$ as majority age (80,4\%), dominated by male workers $(60,7 \%)$, with 25 years as the largest portion of years of service $(62,6 \%)$, and work environment with temperature, lighting, and humidity that is not adequate 18,7\%, 49,5\%, and 36,4\% respectively.

Conclusion : Bivariate analysis showed that humidity influenced the occurrence of SBS complain in PT.X Palembang ( $p$-value $=0,005$ ). To balance out indoor air quality, one of countermeasures that can be applied is to place sansevieria plant as indoor pollutants absorber.

Keywords: Sick Building Syndrome; Humidity; Lighting; Pollutant; Sansevieria Plants

\section{PENDAHULUAN}

Pesatnya pertumbuhan penduduk telah menjadi permasalahan terutama di kota-kota besar yang menyebabkan permintaan lahan semakin meningkat akibat kebutuhan pembangunan di berbagai bidang. Beragam upaya telah dilakukan salah satunya pembangunan infrastruktur gedung dengan rancangan yang tidak membutuhkan lahan luas, seperti pembangunan gedung bertingkat. Era industialisasi juga telah mendorong perusahaan berlomba-lomba untuk mencari peluang terbaik dengan melakukan pembangunan gedung yang dirancang secara vertikal dengan sistem ventilasi sendiri atau ventilation rate yang direduksi untuk memanfaatkan lahan sempit. ${ }^{1,2}$ Rancangan tersebut berguna untuk meminimalisir penggunaan lahan serta meringankan biaya operasional pembangunan. Namun, sejak terjadinya krisis energi tahun 1973 telah menyebabkan perubahan udara di kantor dan rumah hingga menurunkan jumlah udara segar setiap orang dari 20$30 \mathrm{ft}^{3}$ /orang menjadi $5 \mathrm{ft}^{3}$ /orang. Hal ini disebabkan karena kapasitas ventilasi lebih rendah, banyaknya jumlah penghuni dalam ruangan dan akumulasi polusi sehingga dapat membahayakan kesehatan.,

United States Environmental Protection Agency (US EPA) menyatakan bahwa buruknya kualitas udara dalam ruangan merupakan salah satu dari lima masalah kesehatan akibat kondisi lingkungan yang tidak sehat. ${ }^{5}$ Diperkirakan terjadi sekitar tiga juta kematian setiap tahun akibat polusi udara dan sekitar 400-500 juta orang terutama di negara berkembang mengalami masalah polusi udara dalam ruangan dan sebanyak $80-90 \%$ pekerja melakukan aktivitas kerja di dalam ruangan gedung kantor yang bertingkat maupun tidak bertingkat. Pekerja yang bekerja di gedung bertingkat memiliki risiko untuk terpapar bahan polutan akibat sirkulasi udara yang buruk. Dengan demikian, para ahli menyimpulkan bahwa pekerja yang bekerja di dalam ruangan gedung lebih berisiko mengalami gangguan atau gejala kesehatan akibat kualitas udara di dalam ruangan yang kurang baik. Gangguan kesehatan tersebut apabila tidak segera ditindaklanjuti akan menyebabkan kerugian finansial, mengganggu kenyamanan, serta menurunkan produktivitas kerja.,

Sick Building Syndrome adalah kumpulan gejala yang hanya dirasakan seseorang saat beraktivitas di dalam suatu gedung. Gejala tersebut tidak teridentifikasi secara spesifik hingga menyebabkan penghuni ruangan atau bangunan mengalami gangguan kesehatan akibat buruknya kualitas udara. Gejala khas SBS meliputi sakit kepala, sakit mata dan hidung, iritasi tenggorokan, batuk kering, kulit kering atau gatal, pusing dan mual, sulit konsentrasi, serta kelelahan dan berkurangnya kepekaan terhadap bau. Namun, gejala tersebut akan menghilang saat seseorang meninggalkan gedung. ${ }^{8,9}$

Survei menemukan bahwa sebanyak 8.000 hingga 18.000 kasus SBS terjadi setiap tahunnya di Amerika Serikat, sedangkan berdasarkan studi literatur ditemukan bahwa sejak tahun 1970-an, SBS telah menjadi penyakit bangunan terutama di kantor dan sekolah dengan parameter fisik, biologis, kimia, psikososial, dan kondisi individu sebagai kontributor utama penyebab timbulnya SBS. ${ }^{2,10}$ Gedung-gedung bertingkat pada umumnya dilengkapi dengan Air Conditioning (AC) sebagai pengganti ventilasi alami untuk menciptakan lingkungan kerja yang nyaman. Oleh karena AC digunakan sebagai pengganti ventilasi, maka kebersihannya harus dijaga. AC yang jarang dibersihkan akan menjadi tempat bagi mikroorganisme untuk berkembang biak. Maka dari itu, pekerja yang bekerja di gedung ber-AC (suhu lebih dari $23^{\circ} \mathrm{C}$ ) terutama untuk waktu yang lama memiliki 2 hingga 3 kali lebih banyak gejala daripada pekerja yang bekerja di gedung yang dilengkapi dengan ventilasi alami. ${ }^{11}$

Penelitian terhadap pekerja gedung di Warsawa, Polandia ditemukan bahwa sebagain besar pekerja menghabiskan waktu 8 jam kerja dan lebih dari setengah $(68 \%)$ responden merasakan gejala SBS akibat dari suhu udara dalam ruangan yang cukup tinggi $\left(23-24,7^{\circ} \mathrm{C}\right)$ dan kelembaban pada kisaran 48 $65 \% .^{12}$ Penelitian di Beijing, China terkait paparan polusi menghasilkan bahwa gejala SBS yang paling umum dialami adalah kelelahan, gejala pada kulit dan mukosa. ${ }^{13}$ Penelitian yang dilakukan oleh Ikatan Ahli Kesehatan Masyarakat Indonesia (IAKMI) terhadap 350 karyawan dari 18 perusahaan di DKI Jakarta menunjukkan bahwa terdapat $50 \%$ karyawan mengalami SBS, dengan keluhan yang dirasakan seperti flu, sesak napas, mata berair, sering bersin, hidung tersumbat, dan tenggorokan gatal. ${ }^{14}$ Penelitian dari Verayani pada petugas instalasi transfusi darah RSUD Dr. Soetomo menunjukkan bahwa petugas yang mengalami keluhan SBS sebanyak 21 orang 
(84\%) dari 25 orang petugas dan banyak dialami oleh petugas perempuan berumur 26-30 tahun dengan masa kerja $>3$ tahun serta jam kerja 7-10 jam/hari. ${ }^{15}$

Gedung PT. X menunjukkan beberapa ciri karyawannya memiliki risiko untuk mengalami keluhan SBS karena kondisi gedung bertingkat yang tertutup dan memiliki 4 lantai dengan ventilasi sendiri menggunakan AC demi menjaga kestabilan suhu ruangan. Karyawan di PT. X melakukan aktivitas pekerjaan di dalam ruangan selama 8 jam kerja dari hari Senin hingga Jumat dengan jumlah karyawan per ruangan yang cukup banyak. Dengan adanya permasalahan pada kondisi gedung tersebut, maka tindakan pencegahan terhadap keluhan SBS perlu dilakukan. Berdasarkan uraian diatas, tujuan dilakukannya penelitian ini adalah untuk mengetahui faktor-faktor yang mempengaruhi keluhan SBS di gedung PT. X Palembang.

\section{MATERI DAN METODE}

Penelitian ini menggunakan pendekatan kualitatif dengan desain studi cross sectional. Setelah melalui perhitungan sampel, didapatkan jumlah sampel untuk penelitian ini adalah sebanyak 107 karyawan di PT. X. Kriteria inklusi penelitian adalah karyawan yang bekerja $\geq 8$ jam kerja per hari dan bekerja di ruangan tertutup dengan menggunakan AC, sedangkan kriteria esklusi penelitian adalah karyawan yang lebih banyak melakukan aktivitas kerja di luar ruangan atau di lapangan (outdoor) dan karyawan yang sedang hamil. Variabel dalam penelitian ini meliputi Keluahan SBS, usia, jenis kelamin, masa kerja, suhu, pencahayaan, dan kelembaban. Alat yang digunakan untuk mengukur pencahayaan adalah $L u x$ Meter sedangkan untuk suhu dan kelembaban menggunakan Hygrothermometer. Analisis yang digunakan dalam penelitian ini meliputi analisis univariat untuk menunjukkan distribusi frekuensi pada masing-masing variabel dan analisis bivariat untuk mengetahui pengaruh faktor risiko terhadap keluhan SBS dengan menggunakan uji chi square dan uji alternatif fisher exact.

\section{HASIL DAN PEMBAHASAN}

Berdasarkan hasil penelitian pada tabel 1 menunjukan bahwa sebagian besar karyawan di Gedung PT. X mengalami keluhan Sick Building Syndrome yaitu sebesar $75,7 \%$. Selain itu, diketahui juga bahwa mayoritas karyawannya berumur $\leq 40$ tahun $(80,4 \%)$ sementara karyawan yang berumur $>40$ tahun hanya sebesar $19,6 \%$. Sementara, karyawan wanita hanya sebanyak 39,3\%, dengan masa kerja paling banyak 25 tahun yaitu sebesar $62,6 \%$. Dari penelitian ini juga diketahui bahwa suhu yang tidak memenuhi syarat sebesar $18,7 \%$, pencahayaan yang tidak memenuhi syarat yaitu sebesar 49,5\%, dan kelembaban yang tidak memenuhi syarat sebesar $36,4 \%$.

\begin{tabular}{|c|c|c|c|}
\hline No & Variabel & $\mathrm{n}=107$ & $\%$ \\
\hline \multirow[t]{3}{*}{1.} & Keluhan SBS & & \\
\hline & SBS & 81 & 75,7 \\
\hline & Bukan SBS & 26 & 24.3 \\
\hline \multirow[t]{3}{*}{2.} & Usia & & \\
\hline & $>40$ tahun & 21 & 19,6 \\
\hline & $\leq 40$ tahun & 86 & 80,4 \\
\hline \multirow[t]{3}{*}{3.} & Jenis Kelamin & & \\
\hline & Perempuan & 42 & 39,3 \\
\hline & Laki-laki & 65 & 60,7 \\
\hline \multirow[t]{3}{*}{4.} & Masa Kerja & & \\
\hline & 25 tahun & 67 & 62,6 \\
\hline & $<5$ tahun & 40 & 37,4 \\
\hline \multirow[t]{3}{*}{5.} & Suhu & & \\
\hline & Tidak Memenuhi Syarat & 20 & 18,7 \\
\hline & Memenuhi Syarat & 87 & 81,3 \\
\hline \multirow[t]{3}{*}{6.} & Pencahayaan & & \\
\hline & Tidak Memenuhi Syarat & 53 & 49,5 \\
\hline & Memenuhi Syarat & 54 & 50,5 \\
\hline \multirow[t]{3}{*}{7.} & Kelembaban & & \\
\hline & Tidak Memenuhi Syarat & 39 & 36,4 \\
\hline & Memenuhi Syarat & 68 & 63,6 \\
\hline
\end{tabular}

Berdasarkan tabel 2, hasil uji chi square diketahui bahwa kelembaban ( $p$-value $=0,005$; $\mathrm{PR}=$ $1,395 ; 95 \% \mathrm{CI}=1,151-1,691)$ dapat mempengaruhi terjadinya keluhan SBS pada karyawan di Gedung PT. $X$. Dengan tingkat kepercayaan 95\%, diketahui bahwa faktor kelembaban yang tidak memenuhi syarat dapat berisiko menyebabkan terjadinya keluhan SBS sebesar 1,395 kali lebih besar dibandingkan dengan kelembaban yang memenuhi syarat (40-60\% RH). Dari hasil penelitian ini juga menunjukkan umur ( $p$ value $=0,174)$, jenis kelamin $(p$-value $=0,212)$, masa kerja $(p$-value $=1,000)$, suhu $(p$-value $=0,776)$ dan pencahayaan $(p$-value $=0,103)$ tidak berpengaruh terhadap keluhan SBS pada karyawan di gedung PT. $\mathrm{X}$.

Dari hasil uji statistik diketahui bahwa tidak terdapat pengaruh antara umur terhadap keluhan SBS di gedung PT. X ( $p$-value $=0,174)$. Meskipun secara uji statistik faktor umur tidak mempengaruhi keluhan SBS, dari hasil crosstab diketahui bahwa terdapat $61,9 \%$ karyawan yang berumur $>40$ tahun mengalami keluhan SBS, dimana angka ini cukup tinggi sehingga dapat disimpulkan bahwa faktor umur dapat berisiko mempengaruhi keluhan SBS jika tidak diintervensi. Hasil observasi menunjukkan bahwa kelompok umur $>40$ tahun lebih banyak telah menduduki jabatan di dalam struktural. Hal ini dapat diasumsikan bahwa sebagian besar mereka telah memiliki masa kerja yang lama dilihat dari jabatan mereka saat ini, dimana masa kerja berarti lamanya mereka berada di dalam gedung tersebut dalam hitungan tahun, yang artinya bahwa mereka telah terpajan faktor risiko penyebab keluhan SBS selama mereka bekerja di gedung tersebut. 
Tabel 2. Faktor yang Mempengaruhi Keluhan Sick Building Syndrome di Gedung PT. X

\begin{tabular}{|c|c|c|c|c|c|c|c|}
\hline \multirow{2}{*}{ No } & \multirow{2}{*}{ Variabel } & \multicolumn{2}{|c|}{$\begin{array}{c}\text { Keluhan Sick Building } \\
\text { Syndrome }\end{array}$} & \multirow[t]{2}{*}{ P-value } & \multirow[t]{2}{*}{ PR } & \multicolumn{2}{|c|}{$95 \%$ CI } \\
\hline & & $\begin{array}{c}\text { Ya } \\
\mathbf{n}=\mathbf{8 1}\end{array}$ & $\begin{array}{c}\text { Tidak } \\
n=26\end{array}$ & & & Lower & Upper \\
\hline \multirow[t]{3}{*}{1} & Umur & & & \multirow{3}{*}{0,174} & \multirow{3}{*}{0,783} & \multirow{3}{*}{0,550} & \multirow{3}{*}{1,114} \\
\hline & $>40$ tahun & $13(61,9 \%)$ & $8(38,1 \%)$ & & & & \\
\hline & $\leq 40$ tahun & $68(79,1 \%)$ & $18(20,9 \%)$ & & & & \\
\hline \multirow[t]{3}{*}{2} & Jenis Kelamin & & & \multirow{3}{*}{0,212} & \multirow{3}{*}{1,178} & \multirow{3}{*}{0,958} & \multirow{3}{*}{1,448} \\
\hline & Perempuan & $35(83,3 \%)$ & $7(16,7 \%)$ & & & & \\
\hline & Laki-laki & $46(70,8 \%)$ & $19(29,2 \%)$ & & & & \\
\hline \multirow[t]{3}{*}{3} & Masa Kerja & & & \multirow{3}{*}{1,000} & \multirow{3}{*}{1,015} & \multirow{3}{*}{0,812} & \multirow{3}{*}{1,269} \\
\hline & $\geq 5$ tahun & $51(76,1 \%)$ & $16(23,9 \%)$ & & & & \\
\hline & $<5$ tahun & $30(75,0 \%)$ & $10(25,0 \%)$ & & & & \\
\hline \multirow[t]{3}{*}{4} & Suhu & & & \multirow{3}{*}{0,776} & \multirow{3}{*}{1,071} & \multirow{3}{*}{0,833} & \multirow{3}{*}{1,376} \\
\hline & Tidak & $16(80,0 \%)$ & $4(20,0 \%)$ & & & & \\
\hline & $\begin{array}{l}\text { Memenuhi } \\
\text { Memenuhi }\end{array}$ & $65(74,7 \%)$ & $22(25,3 \%)$ & & & & \\
\hline \multirow[t]{4}{*}{5} & Pencahayaan & & & \multirow{4}{*}{0,103} & \multirow{4}{*}{0,815} & \multirow{4}{*}{0,654} & \multirow{4}{*}{1,016} \\
\hline & Tidak & $36(67,9 \%)$ & $17(32,1 \%)$ & & & & \\
\hline & Memenuhi & $45(83,3 \%)$ & $9(16,7 \%)$ & & & & \\
\hline & Memenuhi & & & & & & \\
\hline \multirow[t]{3}{*}{6} & Kelembaban & & & \multirow{3}{*}{$0,005^{*}$} & \multirow{3}{*}{1,395} & \multirow{3}{*}{1,151} & \\
\hline & Tidak & $36(92,3 \%)$ & $3(7,7 \%)$ & & & & 1691 \\
\hline & $\begin{array}{l}\text { Memenuhi } \\
\text { Memenuhi }\end{array}$ & $45(66,2 \%)$ & $23(33,8 \%)$ & & & & 1,091 \\
\hline
\end{tabular}

Ket: $*$ (signifikan)

Hasil penelitian ini sejalan dengan penelitian Harwani et al., yang menyatakan bahwa umur karyawan gedung Menara UMI tidak memiliki pengaruh terhadap kejadian SBS ( $p$-value $=0,376)$ dikarenakan responden kelompok umur dibawah 30 tahun lebih banyak (63\%). ${ }^{16}$ Penelitian Qayyum et al., juga menyebutkan bahwa terdapat korelasi negatif antara umur dengan kejadian SBS. ${ }^{17}$ Sementara, penelitian Asri menyatakan sebaliknya, dimana hasil penelitiannya menunjukkan bahwa faktor umur berhubungan dengan gejala SBS yang dialami oleh pegawai yang berumur <30 tahun karena sering menghabiskan waktu di dalam gedung akibat banyaknya pekerjaan yang harus dilakukan. ${ }^{18}$ Sama seperti halnya hasil penelitian ini yang juga menunjukkan bahwa karyawan yang lebih muda ( $\$ 40$ tahun) lebih banyak menghabiskan waktu di tempat kerja dalam waktu yang cukup lama (lebih dari 8 jam/hari) untuk menyelesaikan pekerjaannya.

Semakin tua umur seseorang menyebabkan daya tahan tubuh, stamina, dan sistem imunitas tubuh menjadi semakin menurun akibat kemampuan jaringan dan sel-sel dalam tubuh yang melemah sehingga risiko kesakitan semakin meningkat. ${ }^{19} \mathrm{Hal}$ ini terjadi secara alamiah dan pasti dialami oleh setiap manusia. National Institute for Safety and Health (NIOSH) menyatakan bahwa pekerja yang berumur lebih dari 40 tahun memiliki risiko mengalami SBS yang lebih tinggi. Pekerja yang berumur lebih tua rentan terpapar zat bersifat toksik yang terkandung dalam udara dan zat tersebut dapat mempengaruhi kekebalan apabila masuk ke dalam tubuh. Dari segi produktivitas kerja, kelompok umur muda merupakan kelompok umur yang produktif sehingga akan lebih dituntut untuk meningkatkan perfoma pekerjaannya dan lebih banyak menghabiskan waktu di tempat kerja. Oleh karena hal tersebut, keluhan SBS pada seseorang tidak dipengaruhi oleh umur tetapi dipengaruhi oleh durasi kerja atau lamanya mereka menghabiskan waktu di dalam gedung (tempat kerja) untuk melakukan pekerjaannya. Terbukti bahwa seseorang yang berumur lebih muda juga dapat berisiko mengalami keluhan SBS. Kondisi tersebut juga akan mempengaruhi produktivitas kerja dan berbanding terbalik dengan teori bahwa semakin tua usia seseorang maka semakin menurun produktivitas kerjanya.

Hasil uji statistik menjelaskan bahwa jenis kelamin tidak mempengaruhi keluhan SBS di gedung PT. X ( $p$-value $=0,212)$. Namun, dari hasil crosstab diketahui bahwa terdapat 83,3\% karyawan perempuan yang mengalami keluhan SBS sementara terdapat 70,8\% karyawan laki-laki yang mengalami keluhan SBS, dimana dapat disimpulkan bahwa karyawan perempuan lebih banyak mengalami keluhan SBS dibandingkan laki-laki. Sehingga meskipun faktor jenis kelamin secara statistik tidak mempengaruhi terjadinya keluhan SBS, jika faktor ini tidak dilakukan upaya penanggulangan maka akan menjadi faktor risiko kedepannya.

Hasil penelitian ini sejalan dengan penelitian Raharjo yang juga menyatakan bahwa tidak terdapat hubungan antara jenis kelamin dengan gejala SBS ( $p$ value $=0,270) .{ }^{20}$ Perempuan akan lebih sering 
merasakan gejala suatu penyakit daripada laki-laki karena respon perempuan lebih sensitif dan peka. ${ }^{21}$ Perempuan umumnya lebih banyak melakukan pekerjaan di dalam ruangan dibandingkan dengan laki-laki. Dimana hasil observasi menunjukkan bahwa perempuan lebih banyak melakukan pekerjaan yang bersifat administratif sementara laki-laki lebih banyak melakukan pekerjaan lapangan sehingga perempuan lebih banyak menghabiskan waktu kerja di dalam gedung. Menurut Stenberg, kondisi fisik perempuan lebih lemah dibandingkan dengan laki-laki, kondisi lingkungan kerja yang buruk diperparah dengan tanggung jawab ganda (pekerjaan di rumah dan di tempat kerja), seringkali diberikan jabatan kerja yang lebih rendah, serta kondisi psikologi kerja yang kurang baik menyebabkan perempuan lebih berisiko mengalami keluhan SBS dibandingkan dengan lakilaki. $^{22}$

Berdasarkan hasil uji statistik diketahui bahwa masa kerja tidak berpengaruh terhadap keluhan SBS di gedung PT. X ( $p$-value $=1,000)$. Namun, dari hasil crosstab dapat dilihat bahwa terdapat lebih banyak karyawan dengan masa kerja $\geq 5$ tahun mengalami keluhan SBS yaitu sbeesar 76,1\% dibandingkan dengan karyawan dengan masa kerja $<5$ tahun $(75,0 \%)$. Sama halnya dengan faktor jenis kelamin, meskipun faktor masa kerja tidak mempengaruhi terjadinya keluhan SBS secara statistik, namun jika tidak diintervensi maka dapat menjadi faktor risiko nantinya. Hasil penelitian ini sejalan dengan penelitian Zaelani yang menyatakan bahwa masa kerja tidak memiliki hubungan dengan keluhan SBS dengan nilai $p$-value sebesar $0,50 .{ }^{23}$ Penelitian Ratodi et al., juga menyatakan bahwa tidak ada hubungan antara masa kerja dengan gejala SBS ( $p$-value = $0,147){ }^{24}$

Semakin lama masa kerja seseorang maka semakin besar kemungkinan terpajan polutan yang terdapat di dalam ruangan tempat bekerja. Gangguan kesehatan yang bersifat kronis dapat terjadi akibat pajanan debu dalam kurun waktu yang lama dengan kadar yang tinggi sehingga tidak dapat ditentukan dalam waktu yang singkat. ${ }^{25}$ Lamanya masa kerja seseorang menentukan banyaknya pajanan zat toksik dari lingkungan kerja yang kurang sehat baik dari segi fisik, kimia, dan biologi sehingga stamina seseorang menjadi menurun dan lebih mudah terserang SBS.

Hasil uji statistik menjelaskan bahwa suhu tidak mempengaruhi terjadinya keluhan SBS di gedung PT. $\mathrm{X}(p$-value $=0,776)$. Namun, dari hasil crosstab dapat dilihat bahwa terdapat lebih banyak karyawan dengan kondisi suhu di lingkungan kerjanya tidak memenuhi syarat mengalami keluhan SBS yaitu sebesar $80,0 \%$ dibandingan dengan karyawan dengan kondisi suhu di lingkungan kerjanya memenuhi syarat yaitu sebesar $74,7 \%$. Sama halnya dengan faktor jenis kelamin dan masa kerja, faktor suhu di lingkungan kerja atau tempat kerja jika tidak diperhatikan maka kedepannya akan menjadi faktor risiko yang mempengaruhi terjadinya keluhan SBS pada karyawan di gedung PT
X Palembang. Hasil penelitian ini sejalan dengan penelitian Sari yang dilakukan di gedung Sampoerna Strategic Jakarta, dimana diketahui bahwa suhu udara dan keluhan SBS tidak memiliki hubungan secara statistik ( $p$-value $=0,266){ }^{26}$

Dalam penelitian ini, syarat yang digunakan untuk mengkategorikan suhu yang memenuhi syarat adalah $18-28^{\circ} \mathrm{C}$. Hasil observasi menunjukkan bahwa terdapat ruangan dengan suhu sebesar $28,3^{\circ} \mathrm{C}$ karena AC yang sering dimatikan. Manusia pada umumnya dapat bekerja dengan rasa nyaman pada suhu 24$26^{\circ} \mathrm{C}^{25}$ Penggunaan AC mempunyai dampak ketidaknyamanan bagi pekerja seperti efek fisiologis yang mempengaruhi sistem saraf, sistem pencernaan, sistem pernapasan, serta iritasi pada kulit dan selaput lendir karena paparan udara di ruangan ber-AC. Dari segi medis, seseorang yang bekerja di ruangan ber-AC dalam waktu yang lama akan menyebabkan respon metabolisme menjadi lemah. ${ }^{11,27}$ NIOSH mengemukakan bahwa buruknya kualitas ventilasi dapat menyebabkan terjadinya SBS. Dalam banyak penelitian, parameter lingkungan yang dapat mempengaruhi kesehatan sebagian besar karena buruknya kualitas udara dalam ruangan. Suhu panas dapat mengurangi kemampuan gerak seseorang, memperlambat pengambilan keputusan karena kurang berkonsentrasi, mengganggu kecermatan kerja otak serta menghambat koordinasi syaraf perasa dan motorik. ${ }^{28}$ Oleh karena itu, perlu adanya peningkatan volume udara luar dengan menggunakan sistem ventilasi sehingga dapat membantu mengurangi terjadinya SBS. Salah satu sistem ventilasi yang dapat digunakan berupa exhaust fan. ${ }^{29,30}$

Hasil uji statistik pada penelitian ini menunjukkan bahwa pencahayaan tidak mempengaruhi terjadinya keluhan SBS di gedung PT. $\mathrm{X}(p$-value $=0,103)$. Hasil penelitian ini sejalan dengan penelitian Husin yang menyatakan bahwa pencahayaan dalam ruangan gedung tidak berhubungan dengan kejadian SBS dengan nilai $p$ value sebesar $0,420 .^{31}$ Selain itu, penelitian yang dilakukan Putra et al. diketahui bahwa pencahayaan di dalam gedung tidak berpengaruh terhadap gangguan kesehatan SBS. ${ }^{32}$ Secara teori, pencahayaan yang terlalu terang dapat menimbulkan gejala sakit kepala dan menurunnya daya konsentrasi. ${ }^{24}$ Hasil analisis penelitian Nuriani et al., menyatakan bahwa responden yang mengalami sakit kepala tidak dapat berkonsentrasi saat bekerja. ${ }^{33}$ Penggunaan komputer merupakan salah satu penyebab terjadinya SBS, dikarenakan pantulan cahaya yang dihasilkan dari layar komputer dapat menyebabkan sakit kepala dan iritasi mata. Pantulan cahaya pada benda seperti kaca juga dapat menyebabkan kesilauan (glare) serta ketidaknyamanan pada penglihatan. Kondisi sakit kepala dan tidak dapat berkonsentrasi ini disebabkan oleh produksi hormon serotonin yang berlebihan dalam tubuh. ${ }^{34}$ Oleh karena itu, pengukuran intensitas pencahayaan secara rutin perlu dilakukan untuk mengetahui kualitas fisik di suatu ruangan memenuhi 
syarat atau tidak sehingga dapat ditentukan langkah yang tepat.

Dari hasil uji statistik diketahui bahwa kelembaban dapat mempengaruhi terjadinya keluhan SBS di gedung PT. X ( $p$-value $=0,005)$. Penelitian ini berbanding lurus dengan penelitian Ridwan et al. pada karyawan unit OK RS Marinir Cilandak yang menyatakan bahwa kelembaban udara di dalam ruangan berpengaruh terhadap kejadian SBS ( $p$-value $=0,013) .{ }^{35}$ Penelitian Norhidayah et al. pada bangunan Perbadanan Kemajuan Bukit Fraser (PKBF) sebagai lokasi penelitian ditemukan total jamur yang cukup tinggi. Hal ini dikaitkan dengan suhu dan persentase kelembaban yang tinggi dan ketidakseimbangan dalam sistem ventilasi yang memungkinkan akumulasi kontaminan dalam ruangan. $^{36}$

Istilah SBS digunakan untuk menggambarkan situasi saat penghuni gedung mengalami efek kesehatan dan ketidaknyamanan. Berdasarkan Peraturan Menteri Kesehatan RI No. 48 tahun 2016 tentang Standar Keselamatan dan Kesehatan Kerja Perkantoran bahwa baku mutu kelembaban di ruang kerja adalah 40-60\% RH. $^{37}$ Beberapa penelitian telah menekankan adanya hubungan antara SBS dengan lingkungan dalam ruangan berdasarkan kondisi kelembaban dan suhu. Kelembaban yang terlalu tinggi menyebabkan pertumbuhan dan penyebaran bakteri, virus, tungau, jamur, serta berpotensi meningkatkan intensitas polutan kimia di udara. Kelembaban menyebabkan mikroba diudara bertahan hidup tergantung pada keadaan lingkungan dan kepadatan dalam ruang. ${ }^{38,39}$ Penelitian Reinikainen di Finlandia menunjukkan bahwa prevalensi gejala seperti pada kulit, hidung, tenggorokan kering, dan hidung tersumbat diperkirakan pada kelembaban relatif kisaran 30-40\% daripada kelembaban relatif kisaran $20-30 \%{ }^{40}$

Kelembaban udara lebih dari $60 \%$ merupakan kondisi lingkungan yang sangat baik bagi pertumbuhan bakteri dan mempertahankan keberlangsungan hidup mikroorganisme parasit karena mengandung uap air di udara, serta melepaskan senyawa volatile yang ada di bangunan seperti formaldehyde, amonia, dan senyawa lain yang mudah menguap dan larut dalam kelembaban yang tinggi menjadi uap yang kemudian terpajan pada pekerja. $^{41}$ Banyaknya mikroorganisme di udara disebabkan oleh kondisi ruangan yang kotor serta memiliki kelembaban yang cukup tinggi kira-kira $85 \%$. Fakta menemukan bahwa $90 \%$ orang yang berada dalam ruangan memiliki risiko terpapar polutan 100 kali lebih banyak akibat sirkulasi udara yang buruk.

Kelembaban udara yang tidak memenuhi syarat dapat menimbulkan gangguan pada sistem pernapasan manusia karena berkaitan langsung dengan udara yang dihirup. Pada saluran pernafasan, terjadi proses inspirasi dan ekspirasi yang menghasilkan sekret (produk hasil dari proses sekresi). Sekret kemudian dibersihkan melalui mekanisme mucociliary transport/mucociliare clearance yang membentuk dahak (mucus) sebagai proses perlawanan non spesifik terhadap infeksi saluran pernaapasan dan dikeluarkan dengan gerakan silia. Dahak yang semakin banyak dan menumpuk menjadi media yang ideal dalam kolonisasi bakteri dan akan menyebabkan infeksi pada saluran pernapasan terutama apabila terjadi gangguan pada mekanisme transportasi mucus dan kerusakan pada sel silia. ${ }^{42}$ Oleh karena itu, kelembaban udara yang tinggi berpotensi menimbulkan berbagai macam gejala yang dapat dikatagorikan sebagai gejala akibat SBS.

Polusi udara baik dalam ruangan maupun diluar ruangan saat ini masih menjadi permasalahan kesehatan dan lingkungan, disebabkan karena semakin berkembangnya aktivitas di bidang industri dan transportasi yang menghasilkan polutan-polutan di udara. Tempat kerja seperti perkantoran atau gedung dapat menggunakan tanaman hias untuk mengurangi dan menyerap polutan tersebut. Tanaman sansevieria atau lidah mertua merupakan salah satu tanaman yang bisa digunakan. Selain memperindah ruangan (estetika), tanaman ini juga memiliki kemampuan untuk menyerap gas polutan di udara. Berdasarkan kajian NASA (National Aeronaustics and Space Administration) tahun 1999, tanaman sansevieria mampu menyerap lebih dari 107 unsur polutan berbahaya di udara seperti karbon dioksida $\left(\mathrm{CO}_{2}\right)$, benzene, formaldehyde, trichloroethylene, dan sebagainya. Jika meletakkan tanaman sansevieria di dalam ruang perkantoran, maka tanaman ini akan mampu menyaring kotoran, bau, dan polutan lainnya sehingga menjadikan udara dalam ruangan akan terasa lebih bersih, segar dan nyaman. ${ }^{43}$ Selain tanaman sansevieria, beberapa tanaman hias lain seperti lili paris dan sirih gading juga mampu menyerap gas polutan berbahaya di dalam ruangan. Namun berdasarkan penelitian Adita dan Ratni, tanaman sansevieria merupakan tanaman yang paling besar tingkat penyerapan polutannya $(44,06 \%)$ sehinga tanaman ini lebih cocok untuk menjadi tanaman hias di ruang perkantoran. ${ }^{44}$

\section{SIMPULAN}

Dari hasil penelitian ini menunjukkan bahwa terdapat $75,7 \%$ karyawan di gedung PT. X mengalami keluhan SBS. Hasil analisis bivariat diketahui bahwa keluhan SBS dipengaruhi oleh kelembaban ( $p$-value $=$ 0,005). Untuk meminimalisir terjadinya keluhan SBS pada karyawan di gedung PT. X dapat dengan meletakkan tanaman hias sebagai penyerap polutan berbahaya yang terdapat di dalam ruangan yang berAC, selain itu juga dapat menyeimbangkan kelembaban di dalam ruangan. Tanaman sansevieria atau lidah mertua dapat menjadi alteratif pilihan agar udara di dalam ruangan menjadi lebih bersih. Rekomendasi dari NASA untuk menempatkan sekitar 15-18 tanaman dalam wadah berdiameter 6-8 inch untuk setiap 1800 kaki persegi ruangan. Selain itu, 
perlu dilakukannya pengukuran secara rutin terhadap kualitas fisik, kimia, dan biologi yang dilakukan setiap 3 bulan sekali.

\section{DAFTAR PUSTAKA}

1. Aditama TY, Andarini SL. Sick Building Syndrome. Med J Indones. 2002;11(2):124-31.

2. Camelia A. Sick Building Syndrome dan Indoor Air Quality. J Ilmu Kesehat Masy. 2011;2(2):79-84.

3. Kosa KH. Indoor Air Quality: Sampling Methodologies. 1st ed. CRC Press; 2010.

4. Jafari MJ, Khajevandi AA, Najarkola SAM, Yekaninejad MS, Pourhoseingholi MA, Omidi L, et al. Association of Sick Building Syndrome with Indoor Air Parameters. Tanaffos. 2015;14(1):55-62.

5. Haris A, Ikhsan M, Rogayah R. Asap Rokok Sebagai Bahan Pencemar dalam Ruangan. CDK189. 2012;39(1):17-9.

6. WHO. WHO Guidelines for Air Quality: Selected Pollutants. WHO Regional Office for Europe. Denmark; 2010.

7. U.S. Department of Labor OSA. Indoor Air Quality in Commercial and Institutional Buildings. U.S: CreateSpace Independent Publishing Platform; 2014.

8. Environmental Protection Agency US, Environments Division I. Indoor Air Facts No. 4 Sick Building Syndrome. EPA - Air \& Radiation (6609J), Research and Development (MD-56). 1991.

9. Smajlović SK, Kukec A, Dovjak M. Association between Sick Building Syndrome and Indoor Environmental Quality in Slovenian Hospitals: A Cross-Sectional Study. Int J Environ Res Public Health. 2019;16(17):1-18.

10. Ghaffarianhoseini A, Alwaer $\mathrm{H}$, Omrany $\mathrm{H}$, Alalouch C, Clements-croome D, Ghaffarianhoseini A, et al. Sick Building Syndrome: Are We Doing Enough? Archit Sci Rev. 2018;61(3):99-121.

11. Burge PS. Sick Building Syndrome. Occup Environ Med. 2004;61(2):185-90.

12. Gladyszewska-Fiedoruk K. Survey Research of Selected Issues the Sick Building Syndrome (SBS) in an Office Building. Environ Clim Technol. 2019;23(2):1-8.

13. Li L, Adamkiewicz G, Zhang Y, Spengler JD. Effect of Traffic Exposure on Sick Building Syndrome Symptoms among Parents/ Grandparents of Preschool Children in Beijing, China. PLoS One. 2015;10(6):1-11.

14. Rahmi A. Hubungan Kualitas Fisik Udara dan Mikrobiologi Udara dengan Kejadian Sick Building Syndrome (Studi Kasus: Perpustakaan Pusat dan Perpustakaan teknik Universitas Indonesia). Program Studi Teknik Lingkungan, Fakultas Teknik, Universitas Indonesia; 2010.

15. Verayani E. Identifikasi Legionella, Kualitas
Udara Ruang dan Keluhan Sick Building Syndrome pada Petugas Instalasi Transfusi Darah RSUD Dr. Soetomo. J Kesehat Lingkung. 2014;10(3):299-305.

16. Harwani NP, Rahman SF, Sunu B, Lingkungan BK, Kesehatan P, Makassar M. Analisis Faktor Demografi dan Ergonomi terhadap Kejadian Gejala Fisik Sick Building Syndrome (SBS) pada Pegawai Gedung Rektorat UMI Kota Makassar. J Sulolipu Media Komun Sivitas Akad dan Masy. 2020;20(1):76-82.

17. Qayyum S, Tariq S, Younas F. Sick Building Syndrome and Job Performance in Women Factory Workers. J Postgrad Med Inst. 2020;34(1):22-8.

18. Asri AN, Pulungan RM, Fitri A musliha. Hubungan Lingkungan Kerja dengan Gejala Sick Building Syndrome pada Pegawai BPJS Kesehatan Depok Tahun 2019. Indones J Publ. 2019;3(1):44-55.

19. Fatmah. Respons Imunitas yang Rendah pada Tubuh Manusia Usia Lanjut. Makara Kesehat. 2006;10(1):47-53.

20. Raharjo HD, Wiediartini, Dermawan D. Analisis Pengaruh Karakteristik Individu dan Faktor Fisik Terhadap Gejala Sick Building Syndrome Pada Pegawai di Gedung Utama Perusahaan Fabrikasi Kapal. J Tek Keselam dan Kesehat Kerja. 2015;Proceeding:5-9.

21. Gomzi M, Bobić J. Sick Building Syndrome: Do We Live and Work in Unhealthy Environment? Period Biol. 2009;111(1):79-84.

22. Stenberg B, Mild KH, Sandström M, Sundell J. A Prevalence Study of the Sick Building Syndrome (SBS) and Facial Skin Symptoms in Office Workers. Med J. 1993;3(2):71-81.

23. Zaelani A. Faktor-faktor yang Mempengaruhi Kejadian Sick Building Syndrome pada Pegawai di Departemen Distribusi Wilayah 1 Graha Sarana PT. Petrokimia Gresik. Universitas Jember; 2015.

24. Ratodi M, Zubaidah T, Marlinae L. Predicting the Sick Building Syndrome (SBS) Occurrence among Pharmacist Assistant in Banjarmasin South Kalimantan. Heal Sci J Indones. 2017;8(2):118-23.

25. Suma'mur. Higiene Perusahaan dan Kesehatan Kerja (HIPERKES). Jakarta: Agung Seto; 2013.

26. Sari OS, Wahyuni D. Faktor-Faktor yang Berhubungan dengan Kejadian Sick Building Syndrome pada Karyawan di Gedung Sampoerna Strategic PT Sampoerna Land Jakarta Tahun 2015. Artik Ilmu Kesehat. 2016;8(1):26-30.

27. Cao B, Shang Q, Dai Z, Zhu Y. The Impact of Air-Conditioning Usage on Sick Building Syndrome during Summer in China. Indoor Built Environ. 2013;22(3):490-7.

28. Oktora B. Hubungan antara Kualitas Fisik Udara dalam Ruang (Suhu dan Kelembaban Relatif) 
dengan Kejadian Sick Building Syndrome (SBS) pada Pegawai Kantor Pusat Perusahaan Jasa Konstruksi X di Jakarta Timur Tahun 2008. Universitas Indonesia; 2008.

29. Sundell J, Lindvall T, Stenberg B. Associations Between Type of Ventilation and Air Flow Rates in Office Buildings and the Risk of SBSSymptoms among Occupants. Environ Int. 1994;20(2):239-51.

30. Pemerintah Provinsi DKI Jakarta. Sistem Pengkondisian Udara \& Ventilasi. Penataan Udar. 2012;2(38):1-48.

31. Husin H, Suhendro. Analisis Keluhan Sick Building Syndrome (SBS) pada Pegawai di Biro Umum Sekretariat Daerah Provinsi Bengkulu. 2015.

32. Putra I, Ikhtiar M, Emelda A. Analisis Mikroorganisme Udara terhadap Gangguan Kesehatan dalam Ruangan Administrasi Gedung Menara UMI Makassar. Wind Heal J Kesehat. 2018;1(2):68-75.

33. Nuriani, Rahmawati, Kurniatuhadi R. Hubungan Keberadaan Koloni Bakteri Staphylococcus dan Faktor Fisikawi dalam Ruangan Terhadap Kejadian Sick Building Syndrome (SBS) pada Petugas Perpustakaan Universitas Tanjungpura. J Protobiont. 2017;6(3):240-8.

34. Mccoll SL, Veitch JA. Full-Spectrum Fluorescent Lighting: A Review of its Effects on Physiology and Health. Psychol Med. 2001;31(6):949-64.

35. Ridwan AM, Nopiyanti E, Susanto AJ. Analisis Gejala Sick Building Syndrome Pada Pegawai Di Unit OK Rumah Sakit Marinir Cilandak Jakarta Selatan. J Kesehat Masy. 2018;2(1):11633.

36. Norhidayah A, Lee CK, Azhar MK, Nurulwahida S. Indoor Air Quality and Sick Building Syndrome in Three Selected Buildings. Procedia Eng. 2013;53(2013):93-8.

37. Kementerian Kesehatan RI. Peraturan Menteri Kesehatan Republik Indonesia Nomor 48 Tahun 2016 tentang Standar Keselamatan dan Kesehatan Kerja Perkantoran. 2016.

38. Sookchaiya T, Monyakul V, Thepa S. Assessment of the Thermal Environment Effects on Human Comfort and Health for the Development of Novel Air Conditioning System in Tropical Regions. Energy Build. 2010;42(10):1692-702.

39. Amin NDM, Akasah ZA, Razzaly W. Architectural Evaluation of Thermal Comfort: Sick Building Syndrome Symptoms in Engineering Education Laboratories. Procedia Soc Behav Sci. 2015;204(November 2014):19_ 28.

40. Reinikainen LM. The Effect of Air Humidification on Different Symptoms in Office Workers-An Epidemiologic Study. Environ Int. 1991;17(4):243-50.
41. Fardiaz S. Polusi Air \& Udara. Yogyakarta: Kanisius; 1992.

42. Cole P. 'Modicikation in inspired air'. In: Mathew, O.P. Respiratory Function of the Upper Airway'. Lung Biol Heal Dis. 1988;

43. Rosha PuT, Fitriyana MN, Ulfa SF, Dharminto. Pemanfaatan Sansevieria Tanaman Hias Penyerap Polutan sebagai Upaya Mengurangi Pencemaran Udara di Kota Semarang. J Ilm Mhs Fak Kesehat Masy Univ Diponegoro. 2013;3(1):1-6.

44. Adita BR, Ratni N. Tingkat Kemampuan Penyerapan Tanaman Hias dalam Menurunkan Polutan Karbon Monoksida. J Ilm Tek Lingkung. 2013;4(1):54-60. 